JURNAL KEBIDANAN

Vol 6, No 3, Juli 2020 : 329-334

\title{
PEMBERIAN ASI DAN BBLR BERHUBUNGAN DENGAN KEJADIAN STUNTING PADA BALITA USIA 12-36 BULAN
}

\author{
Ita Novianti', Diana Mardianti², Asrianti Safitri Muchtar ${ }^{3}$ \\ ${ }^{1}$ Akademi Kebidanan Batari Toja Watampone \\ email: ita.novianti91@gmail.com \\ ${ }^{2}$ Akademi Kebidanan Batari Toja Watampone \\ email: dianayhunus@gmail.com \\ ${ }^{3}$ Akademi Kebidanan Batari Toja Watampone \\ email: anthy.muchtar@gmail.com
}

\begin{abstract}
Background: One of nutritional problems in toddlers that requires more attention is stunting based on the $T B / U$ index. Stunting is a condition of short or too short body that it exceeds the SD-2 deficit below the median length or height of body that affect to the failure of reaching normal and healthy height which is associated with the child's age. Stunting is a condition where chronic malnutrition is caused by poor nutritional intake, LBW (Low Birth Weight) and a history of disease. It includes unbalanced food and inappropriate exclusive breastfeeding, which is caused by limited food consumption.

Purpose: To determine the relationship of breastfeeding and low birth weight infants to the incidence of stunting in infants aged 12-36 months in the working area of Puskesmas Ulaweng in 2019.

Method: This study used a cross sectional design. The population were 105 young people aged 12-36 months who were registered at the Posyandu. The sample in this study were 52 people. Purposive sampling technique sampling and data collection by questionnaire were applied. Data were processed using SPSS 20 and univariate and bivariate analysis with chi-square statistical tests, and presented in the form of frequency distribution tables.

Result: There is a relationship between exclusive breastfeeding and the occurrence of Stunting, where the value $(p)=.000$, there is a relationship between $L B W$ and the event of Stunting, where the value $(p)=.000$.

Conclusion: There is a relationship of breastfeeding and low birth weight to stunting in the work area of Puskesmas Ulaweng.

Suggestion: Further increase counseling on WUS about breastfeeding and stunting
\end{abstract}

Keywords: Breastfeeding, Low Birth Weight, and Stunting Event

\section{ABSTRAK}

Latar Belakang : Salah satu masalah gizi pada balita yang mendapat banyak perhatian yaitu stunting berdasarkan indeks TB/U. Stunting merupakan keadaan tubuh yang pendek dan sangat pendek hingga melampaui deficit -2 SD di bawah median panjang atau tinggi badan, yang mengakibatkan kegagalan dalam mencapai tinggi badan yang normal dan sehat sesuai usia anak. Stunting merupakan suatu kondisi dimana kurang gizi kronis yang disebabkan oleh asupan gizi yang kurang, BBLR (Berat Badan Lahir Rendah) dan riwayat penyakit. Asupan makanan yang tidak seimbang termasuk dalam pemberian ASI eksklusif yang tidak sesuai yang diakibatkan karena keterbatasan makanan yang dikonsumsi.

Tujuan: Untuk mengetahui hubungan pemberian asi dan berat badan lahir rendah dengan kejadian stunting pada balita usia 12-36 bulan di wilayah kerja puskesmas ulaweng tahun 2019.

Metode: Penelitian ini menggunakan desain cross sectional. Populasi berjumlah 105 orang balia usia 1236 bulan yang tercatat di posyandu. Sampel dalam penelitian ini adalah 52 orang. Teknik pengambilan sampel purposive sampling, pengumpulan data dengan kuesinoer. Data diolah menggunakan SPSS versi 20 dan analisa secara univariat dan bivariat dengan uji statistic chi-square serta disajikan dalam bentuk tabel distribusi frekuensi.

Hasil: Ada hubungan pemberian ASI Eksklusif dengan Kejadian Stunting dimana diperoleh nilai $(p)=, 000$ ada hubungan BBLR dengan kejadian Stunting dimana diperoleh nilai $(p)=, 000$.

Kesimpulan: Terdapat hubungan Pemberian ASI dan Berat Badan Lahir Rendah dengan kejadian stunting di wilayah kerja Puskesmas Ulaweng.

Saran : Lebih meningkatkan penyuluhan pada WUS tentang pemberian ASI dan Stunting

Kata Kunci : Pemberian ASI, Berat Badan Lahir Rendah dan Kejadian Stunting 


\section{PENDAHULUAN}

Usia balita merupakan masa dimana proses pertumbuhan dan perkembangan terjadi sangat pesat. Pada masa ini balita membutuhkan asupan gizi yang cukup dalam jumlah dan kualitas yang lebih banyak karena balita umumnya mempunyai aktivitas fisik yang cukup tinggi dan masih dalam proses belajar.(Welasih \& Wirjatmadi, 2012)

Salah satu masalah gizi pada balita yang mendapat banyak perhatian yaitu stunting berdasarkan indeks TB/U. Stunting merupakan keadaan tubuh yang pendek dan sangat pendek hingga melampaui defisit $-2 \mathrm{SD}$ di bawah median panjang atau tinggi badan, yang mengakibatkan kegagalan dalam mencapai tinggi badan yang normal dan sehat sesuai usia anak (Irviani, 2014).

Stunting merupakan suatu kondisi dimana kurang gizi kronis yang disebabkan oleh asupan gizi yang kurang dalam jangka waktu yang cukup lama akibat pemberian makanan yang tidak sesuai dengan kebutuhan gizi. Pertumbuhan merupakan salah satu indikator terbaik untuk melihat status gizi dan kesehatan anak usia bawah lima tahun (balita). Pertumbuhan pada masa balita terutama baduta (bawah dua tahun) merupakan salah satu indikator status kesehatan di masa dewasa. Gangguan pertumbuhan yang terjadi pada usia baduta meningkatkan risiko penyakit kronis pada usia dewasa. Hasil penelitian menemukan bahwa kejadian stunting meningkat pada usia 1 tahun sampai dua tahun.

Penyebab utama stunting diantaranya adalah asupan ASI (Air Susu Ibu) atau asupan zat gizi yang tidak mencukupi untuk mendukung pertumbuhan dan perkembangan yang cepat pada masa bayi dan anak-anak, hambatan pertumbuhan dalam kandungan, berat badan lahir rendah dan seringnya terkena penyakit infeksi selama awal masa kehidupan. (Ernawati, Muljati, Dewi, \& Safitri, 2014).

Jika dilihat dari umur balita, ternyata kejadian stunting banyak terdapat pada usia 12 hingga 59 bulan. Padahal teori menjelaskan bahwa $90 \%$ pertumbuhan otak manusia terjadi sejak janin sampai sebelum anak berusia lima tahun. Bahkan, $70 \%$ pertumbuhan otak itu terjadi di bawah usia 2 tahun. Proses seperti ini tidak dijumpai di periode ini dijuluki masa emas atau periode kritis (Almatsier, 2013).

Menurut Unicef Framework ada 3 faktor utama penyebab stunting yaitu asupan makanan yang tidak seimbang, BBLR (Berat Badan Lahir Rendah) dan riwayat penyakit. Asupan makanan yang tidak seimbang termasuk dalam pemberian ASI eksklusif yang tidak sesuai yang diakibatkan karena keterbatasan makanan yang dikonsumsi (Wiyogowati, 2012).

BBLR terkait dengan mortalitas dan morbiditas janin dan neonatal, gangguan pertumbuhan, gangguan perkembangan kognitif dan penyakit kronis di kehidupan mendatang. Bayi dengan Berat Badan Lahir Rendah (BBLR) di negara-negara berkembang lebih cenderung mengalami retardasi pertumbuhan intrauterin karena gizi ibu yang buruk dan angka infeksi yang meningkat jika di bandingkan dengan negaranegara maju. (Fitri, 2012)

Menurut World Health Organization (2014), balita pendek akan menjadi masalah kesehatan masyarakat jika prevalensi lebih dari $20 \%$, di Indonesia, prevalensi balita pendek pada tahun 2013 sebesar $37,2 \%$ sehingga masalah ini harus ditanggulangi. WHO mencatat bahwa di dunia lebih dari 2 juta kematian anak $5-12$ tahun berhubungan langsung dengan gizi terutama akibat stunting dan sekitar 1 juta kematian akibat KEP (Kekurangan Energi dan Protein), vitamin A dan zinc (WHO, 2014).

Berdasarkan Riset Kesehatan Dasar (2013), prevalensi balita pendek juga mengalami peningkatan dibandingkan tahun sebelumnya, 2010 (35,6\%), dan 2007 (36,8\%). Selain itu, prevalensi balita pendek di Indonesia relatif tertinggi dibandingkan negara-negara tetangga seperti Malaysia (17\%), Myanmar (35\%), Vietnam (23\%), dan Thailand (16\%) (Kemenkes, 2013).

Data yang diperoleh dari Dinas kesehatan Provinsi Sulawesi Selatan pada tahun 2017 prevalensi stunting 34,8\%. (DinkesPropinsiSulSel, 2017).

Diketahui prevalensi balita stunting di Kabupaten Bone yaitu pada tahun 2018 sebanyak 1324 (16,25\% sangat pendek dan $74,75 \%$ pendek). Berdasarkan data yang diperoleh dari Dinas Kesehatan Kab. Bone prevalensi stunting yang terbanyak pada tahun 2018 yaitu Puskesmas Ulaweng sebanyak 62 balita (4,90\%). Berdasarkan data di atas, diperoleh bahwa prevalensi stunting masih cukup tinggi di Puskesmas Ulaweng. Oleh karena itu, perlu dilakukan penanganan yang serius terkait masalah ini (Dinkes, 2018).

\section{METODE PENELITIAN}

Jenis penelitian observasional analitik dengan rancangan cross sectional study. Penelitian ini telah dilaksanakan di Puskesmas Ulaweng.

Populasi pada penelitian ini adalah semua balita usia 12-36 bulan di wilayah kerja puskesmas kecamatan Ulaweng Kabupaten Bone yang berjumlah 105 balita dan sampel dalam penelitian 
ini adalah 52 orang.

Teknik pengambilan sampel yang digunakan dalam penelitian ini adalah Purposive Sampling yaitu berdasarkan kriteria yang telah ditentukan.

Instrumen pengumpulan data adalah kuesioner. Pengumpulan data meliputi data primer mengenai umur, pekerjaan, paritas, berat badan. Data primer diperoleh langsung dari responden melalui pengisian lembar kuesioner maupun wawancara yang meliputi data tentang hubungan Pemberian ASI dan BBLR dengan kejadian Stunting. Data sekunder diperoleh dari dinas kesehatan kabupaten bone dan diperoleh buku registrasi kunjungan pasien di Puskesmas Ulaweng.

Data yang telah dikumpulkan diinput ke komputer dan dianalisis menggunakan program SPSS 22. Analisis data dilakukan secara deskriptif dan analitik. Secara deskriptif data disajikan dalam bentuk tabel distribusi frekuensi disertai penjelasan dan persentase. Sedangkan untuk menganalisis hubungan variabel antara pemberian ASI eksklusif dan BBLR dengan kejadian stunting pada balita usia 12-36 bulan menggunakan uji chi-Square.

\section{HASIL PENELITIAN}

Deskripsi Karakteristik Responden

Tabel 1.

Distribusi Frekuensi Karakteristiklbu

Responden Berdasarkan Umur, Pendidikan, Pekerjaan di Wilayah Kerja Puskesmas Ulaweng

\begin{tabular}{lcc}
\hline \multicolumn{1}{c}{ Karakteristik } & Frekuensi (f) & Persentase (\%) \\
\hline Umur & & \\
20-35 Tahun & 45 & 87 \\
> 35 Tahun & 7 & 13 \\
Pendidikan & & \\
SD & 10 & 19 \\
SMP & 25 & 48 \\
SMA & 15 & 29 \\
PT & 2 & 4 \\
Pekerjaan & & \\
Bekerja & 4 & 8 \\
Tidak Bekerja & 48 & 92 \\
\hline
\end{tabular}

Tabel 1. menunjukkan bahwa dari 52 responden yang diteliti, ibu responden dengan kriteria umur 20-35 tahun sebanyak 45 responden $(87 \%)$, dan ibu responden dengan kriteria umur $>35$ tahun sebanyak 7 responden (13\%). Sementara dari 52 responden yang diteliti, jumlah responden yang paling dominan ialah responden yang berpendidikan SMP sebanyak 25 responden (48\%), dan responden yang berpendidikan
Perguruan Tinggi sebanyak 2 responden (4\%). Dan dari 52 responden yang diteliti terdapat ibu responden tidak bekerja sebanyak 48 responden $(92 \%)$, dan ibu responden yang bekerja sebanyak 4 responden (8\%).

Tabel 2.

Distribusi Frekuensi Pemberian ASI Eksklusif di Wilayah Kerja Puskesmas Ulaweng.

\begin{tabular}{ccc}
\hline $\begin{array}{c}\text { Pemberian ASI } \\
\text { Eksklusif }\end{array}$ & $\begin{array}{c}\text { Frekuensi } \\
(\mathrm{f})\end{array}$ & $\begin{array}{c}\text { Presentasi } \\
(\%)\end{array}$ \\
\hline Ya & 44 & 85 \\
Tidak & 8 & 15 \\
\hline Total & 52 & 100 \\
\hline
\end{tabular}

Tabel 2. menunjukkan bahwa dari 52 responden yang diteliti, terdapat responden yang memberikan ASI Eksklusif sebanyak 44 responden $(85 \%)$ dan responden yang tidak memberikan ASI Eksklusif sebanyak 8 responden (15\%).

Tabel 3.

Distribusi Frekuensi Kejadian BBLR di Wilayah Kerja Puskesmas Ulaweng

\begin{tabular}{lcc}
\hline Kejadian BBLR & Frekuensi (f) & Presentasi (\%) \\
\hline BBLR & 14 & 27 \\
Tidak BBLR & 38 & 73 \\
\hline \multicolumn{1}{c}{ Total } & 52 & 100 \\
\hline
\end{tabular}

Tabel 3. menunjukkan bahwa dari 52 responden yang diteliti, terdapat responden dalam kategori tidak BBLR sebanyak 38 responden (73\%) dan responden dalam kategori BBLR sebanyak 14 responden (27\%).

Tabel 4

Distribusi Frekuensi Kejadian Stunting di Wilayah Kerja Puskesmas Ulaweng

\begin{tabular}{lcc}
\hline Kejadian Stunting & $\begin{array}{c}\text { Frekuensi } \\
(\mathrm{f})\end{array}$ & $\begin{array}{c}\text { Presentasi } \\
(\%)\end{array}$ \\
\hline Stunting & 43 & 83 \\
Tidak Stunting & 9 & 17 \\
\hline \multicolumn{1}{c}{ Total } & 52 & 100 \\
\hline
\end{tabular}

Tabel 4. menunjukkan bahwa dari 52 responden yang diteliti, responden dalam kategori tidak stunting sebanyak 43 responden (83\%), dan respondent dalam kategori stunting sebanyak 9 responden (17\%). 


\section{Deskripsi Pemberian ASI Ekslusif dengan Kejadian Stunting}

Tabel 5.

Hubungan pemberian ASI dengan Kejadian Stunting Pada Balita Usia 12-36 Bulan di Puskesmas Ulaweng

\begin{tabular}{|c|c|c|c|c|c|c|c|}
\hline \multirow{3}{*}{$\begin{array}{l}\text { Pemberian Asi } \\
\text { Eksklusif }\end{array}$} & \multicolumn{6}{|c|}{ Kejadian Stunting } & \multirow{3}{*}{$P$} \\
\hline & \multicolumn{2}{|c|}{ Tidak Stunting } & \multicolumn{2}{|c|}{ Stunting } & \multicolumn{2}{|c|}{ Jumlah } & \\
\hline & $\mathrm{n}$ & $\%$ & $\mathrm{~N}$ & $\%$ & $\mathrm{~N}$ & $\%$ & \\
\hline $\mathrm{Ya}$ & 42 & 81 & 2 & 4 & 44 & 100 & \\
\hline Tidak & 1 & 2 & 7 & 13 & 8 & 100 & 000, \\
\hline
\end{tabular}

Tabel 5. menunjukkan bahwa dari 52 responden yang diteliti, responden yang memberikan ASI eksklusif dan tidak mengalami stunting sebanyak 42 (81\%), sedangkan responden yang memberikan ASI dan mengalami stunting sebanyak 2 (4\%), responden yang tidak memberikan ASI dan tidak mengalami stunting sebanyak $1(2 \%)$, dan responden yang tidak memberikan ASI dan mengalami stunting sebanyak $7(13 \%)$. Berdasarkan hasil uji analisis chi square menunjukkan bahwa nilai $p=, 000(p<0,05)$ yang berarti $\mathrm{Ha}$ diterima dan $\mathrm{H}_{0}$ ditolak sehingga disimpulkan bahwa ada hubungan bermakna antara Pemberian ASI dengan kejadian stunting di Wilayah Kerja Puskesmas Ulaweng.

\section{Deskripsi Berat Badan Lahir Rendah dengan Kejadian Stunting}

Tabel 6.

Hubungan Berat Badan Lahir Rendah Dengan Kejadian Stunting Pada Balita Usia 12-36 bulan di Wilayah Kerja Puskesmas Ulaweng

\begin{tabular}{lccccccc}
\hline \multirow{2}{*}{ Kejadian BBLR } & \multicolumn{6}{c}{ Kejadian Stunting } & \multirow{2}{*}{$p$} \\
\cline { 2 - 7 } & \multicolumn{2}{c}{ Tidak Stunting } & \multicolumn{2}{c}{ Stunting } & \multicolumn{2}{c}{ Jumlah } & \\
\cline { 2 - 7 } & $\mathrm{n}$ & $\%$ & $\mathrm{n}$ & $\%$ & $\mathrm{~N}$ & $\%$ & \multirow{2}{*}{000} \\
\hline BBLR & 5 & 10 & 9 & 17 & 14 & 100 & \multirow{2}{*}{ Tidak BBLR } \\
\hline
\end{tabular}

Tabel 6. menunjukkan bahwa dari 52 responden yang diteliti, responden yang BBLR dan tidak stunting sebanyak $5(10 \%)$, sedangkan responden yang BBLR dan mengalami stunting sebanyak $9(17 \%)$, dan responden yang tidak BBLR dan tidak stunting sebanyak $38(73 \%)$. Berdasarkan hasil uji analisis chi square menunjukkan bahwa nilai $p=, 000(p<0,05)$ yang berarti $\mathrm{Ha}$ diterima dan $\mathrm{H}_{0}$ ditolak sehingga disimpulkan bahwa ada hubungan bermakna antara BBLR dengan kejadian stunting di Wilayah Kerja Puskesmas Ulaweng.

\section{PEMBAHASAN}

Hubungan Pemberian ASI dengan Kejadian Stunting pada Balita Usia 12-36 bulan.

Hasil penelitian menunjukkan bahwa dari 52 responden diperolehsebanyak42 responden (81\%) yang memberikan ASI Eksklusif dan tidak mengalami stunting, sebanyak 1 responden (2\%) yang tidak memberikan ASI dan tidak mengalami stunting, sebanyak 2 responden (4\%) yang memberikan ASI Eksklusif dan mengalami stunting dan sebanyak 7 responden (13\%) yang tidak memberikan ASI Eksklusifdanmengalami stunting. Berdasarkan hasil uji analisis chi square menunjukkan bahwa nilai $p=, 000$

$(p<0,05)$ yang berarti $\mathrm{Ha}$ diterima dan $\mathrm{H}_{0}$ ditolak sehingga disimpulkan bahwa ada hubungan bermakna antara Pemberian ASI Eksklusif dengan kejadian stunting di Wilayah Kerja Puskesmas Ulaweng tahun2019.

ASI Eksklusif merupakan asupan gizi yang sesuai dengan dengan kebutuhan akan membantu pertumbuhan dan perkembangan anak. Bayi yang tidak mendapatkan ASI Eksklusif dengan cukup berarti memiliki asupan gizi yang kurang baik dan dapat menyebabkan kekurangan gizi salah salah satunya dapat menyebabkan stunting.

Sesuai dengan Syafrudin (2009) bahwa salah satu manfaat ASI eksklusif adalah mendukung pertumbuhan bayi terutama tinggi 
badan karena kalsium ASI lebih efisien diserap dibanding susu pengganti ASI atau susu formula. Sehingga bayi yang diberikan ASI Eksklusif cenderung memiliki tinggi badan yang lebih tinggi dan sesuai dengan kurva pertumbuhan dibanding dengan bayi yang diberikan susu formula. ASI mengandung kalsium yang lebih banyak dan dapat diserap tubuh dengan baik sehingga dapat memaksimalkan pertumbuhan terutama tinggi badan dan dapat terhindar dari resiko stunting.

ASI juga memiliki kadar kalsium, fosfor, natrium, dan kalium yang lebih rendah daripada susu formula, sedangkan tembaga, kobalt, dan selenium terdapat dalam kadar yang lebih tinggi. Kandungan ASI ini sesuai dengan kebutuhan bayi sehingga dapat memaksimalkan pertumbuhan bayi termasuk tinggi badan. Berdasarkan hal tersebut dapat dipastikan bahwa kebutuhan bayi terpenuhi, dan status gizi bayi menjadi normal baik tinggi badan maupun berat badan jika bayi mendapatkan ASI Eksklusif. (Roesli. 2015).

Hasil penelitian ini sejalan dengan penelitian sebelumnya oleh Arifin (2012) yang berjudul analisis sebaran dan faktor resiko stunting pada balita di Kabupaten Purwakarta 2012. Hasil penelitian diperoleh hasil analisis multivariate faktor yang paling dominan adalah pemberian ASI yang mempengaruhi stunting 3,1\% (OR 95\% 1.4346.835). Hasil penelitian juga menunjukkan bahwa terdapat 3 responden yang diberikan ASI eksklusif memiliki tinggi badan sangat pendek. Hasil penelitian menunjukkan bahwa 3 responden tersebut lahir dengan BBLR dimana berat badan lahir kurang akan mempengaruhi pertumbuhan anak selanjutnya termasuk tinggi badan anak. Selain itu 2 diantaranya ibu memiliki riwayat KEK saat hamil sehingga kebutuhan nutrisi dalam kandungan kurang tercukupi dengan baik dan berpengaruh terhadap pertumuhan selanjutnya dan beresiko mengalami stunting. Hal ini sesuai dengan teori bahwa ASI Eksklusif bukan merupakan satusatunya faktor yang mempengaruhi kejadian stunting terdapat faktor lain seperti asupan gizi, penyakit infeksi, ketersediaan pangan, status Gizi ibu hamil, berat badan lahir, panjang badan lahir dan $\mathrm{Mp} \mathrm{ASI}$. Penelitian juga menunjukkan 3 responden dengan tinggi badan normal namun tidak mendapatkan ASI Eksklusif dimana 1 responden dengan penghasilan di atas UMR sehingga memiliki asupan nutrisi yang cukup baik untuk mendukung pertumbuhan anak termasuk tinggi badan dan 2 responden adalah IRT sehingga memiliki waktu yang lebih untuk mengasuh dan merawat anaknya dan memberikan gizi yang baik.

\section{Hubungan Berat Badan Lahir Rendah Dengan Kejadian Stunting pada Balita Usia 12-36 bulan.}

Berdasarkan hasil penelitian diperoleh dari 52 responden diperoleh sebanyak 5 responden $(10 \%)$ yang BBLR dan tidak stunting, sebanyak 38 responden $(73 \%)$ yang tidak BBLR dan tidak stunting dan sebanyak 9 responden (17\%) yang BBLR dan mengalami stunting. Berdasarkan hasil uji analisis chi square menunjukkan bahwa nilai $p=$ ,000 ( $p<0,05)$ yang berarti $\mathrm{Ha}$ diterima dan $\mathrm{H}_{0}$ ditolak sehingga disimpulkan bahwa ada hubungan bermakna antara BBLR dengan kejadian stunting di Wilayah Kerja Puskesmas Ulaweng tahun 2019.

BBLR juga mengalami gangguan saluran pencernaan karena saluran pencernaan belum berfungsi sempurna, belum dapat menyerap lemak dan mencerna protein yang dapat mengakibatkan kurangnya cadangan zat gizi dalam tubuh. Hal ini mengakibatkan pertumbuhan bayi BBLR akan terganggu, kemudian jika hal ini berlanjut dengan pemberian makanan yang tidak mencukupi, bayi sering mengalami infeksi, serta perawatan kesehatan yang tidak baik, maka dapat menyebabkan anak mengalami stunting (Nasution, Nurdiyati dan Huriyati,2014)

Penelitian ini sejalan dengan penelitian yang telah dilakukan oleh Nasution, Nurdiyati dan Huriyati (2014) menunjukkan bahwa terdapat hubungan antara BBLR dengan kejadian stunting pada anak usia 6 - 24 bulan yaitu 5,6 kali lebih tinggi mengalami resiko kejadian stunting pada anak dengan riwayat BBLR dibandingkan anak yang lahir dengan berat badan normal. Kejadian ini terjadi karena bayi yang lahir dengan BBLR sejak dalam kandungan sudah mengalami retardasi pertumbuhan intrauterin dan dapat berlanjut sampai usia selanjutnya setelah dilahirkan yaitu pertumbuhan dan perkembangan lebih lambat dari bayi yang dilahirkan normal dan sering gagal menyusul tingkat pertumbuhan yang seharusnya dicapai pada usia setelah lahir.

\section{KESIMPULAN}

Berdasarkan Penelitian ini, disimpulkan bahwa sebagian besar responden melahirkan bayi tidak BBLR serta memberikan ASI Eksklusif. Berdasarkan hasil analisis diketahui bahwa Ada hubungan bermakna antara pemberian ASI Eksklusif dengan kejadian stunting dan ada hubungan bermakna antara BBLR dengan kejadian stunting pada balita Usia 12-36 bulan di Wilayah Kerja Puskesmas Ulaweng. 


\section{SARAN}

Disarankan untuk mengembangkan variabel yang belum diteliti dengan analisis lebih mendalam serta menggunakanmetode penelitian berupa wawancara mendalam agar data yang diperoleh lebih baik lagi.

\section{DAFTAR PUSTAKA}

Abas. (2012). Hubungan Faktor Asupan Makanan dan Kondisi Penyakit dengan Kejadian BBLR di RSUD DR. Soedarso Pontianak. Jurnal Vokasi Kesehatan, 154-160.

Achadi. (2016). Hubungan Asupan Protein, Seng, Zat Besi, dan Riwayat Penyakit Infeksi dengan Kejadian Stunting pada Anak Usia 13 tahun di Desa Suci Gresik. Jurnal of Nutrition College, 520-526.

Sunita, A. (2009). Prinsip dasar ilmu gizi. Jakarta: Gramedia Pustaka Utama, 51-75.

Anisa. (2012). Faktor yang Berhubungan dengan Kejadian Stunting pada Balita Usia 25-60 Bulan di Kelurahan Kalibaru Depok Tahun 2012. Skripsi Studi Gizi Kesehatan Masyarakat UI .

Dinkes, K. B. (2018). Profil Kesehatan Kabupaten Bone. Kabupaten Bone: Dinas Kesehatan Kabupaten Bone.

DinkesPropinsiSulSel. (2017). Profil Kesehatan Sulawesi Selatan Tahun 2017. Makassar: Dinas Kesehatan Propinsi Sulawesi Selatan.

Ernawati, F., Muljati, S., \& Safitri, A. (2014). Hubungan panjang badan lahir terhadap perkembangan anak usia 12 bulan. Nutrition and Food Research, 37(2), 109-118.

Fitri, A. R., \& Nita, N. (2012). Buku Pintar Asuhan Keperawatan Bayi \& Balita. Cakrawala IImu. Yokyakarta.

Hanum, S., Hasanah, O., \& Elita, V. (2014). Gambaran Morbiditas Bayi dengan Berat Badan Lahir Rendah (BBLR) di Ruang Perinatologi RSUD Arifin Achmad Pekanbaru (Doctoral dissertation, Riau University).
IDAl. (2009). Buku Ajar Hematologi - Onkologi Anak. Jakarta: EGC.

Rahmayana, R. (2014). Hubungan pola asuh ibu dengan kejadian stunting anak usia 24-59 bulan di posyandu asoka ii wilayah pesisir kelurahan Barombong kecamatan Tamalate kota Makassar Tahun 2014 (Doctoral dissertation, Universitas Islam Negeri Alauddin Makassar).

Kemenkes. (2013). Laporan Nasional Riset Kesehatan Dasar. Jakarta: Badan Penelitian dan Pengembangan Kementerian Kesehatan Rl.

Nasar, S. S. (2016). Tata laksana nutrisi pada bayi berat lahir rendah. Sari pediatri, 5(4), 165-70.

Nasution, D., \& Nurdiati, D. S. (2014). Hubungan berat badan lahir rendah (bblr) dengan kejadian stunting pada anak usia 6-24 bulan di Kota Yogyakarta (Doctoral dissertation, [Yogyakarta]: Universitas Gadjah Mada).

Nurlinda. (2013). Faktor Risiko yang Berhubungan dengan Kejadian Bayi Berat Lahir Rendah di Kecamatan Semampir Surabaya. Media Gizi Indonesia, 71-80.

Putra, S. R. (2012). Asuhan Neonatus Bayi dan Balita untuk Keperawatan dan Kebidanan. Yogyakarta: D-medika.

Subkhan. (2011). Kerangka Teori Faktor- Faktor yang Mempengaruhi BBLR. Jakarta: EGC.

Surasmi, A., Handayani, S., \& Kusuma, H. N. (2003). Perawatan bayi resiko tinggi. Jakarta: EGC.

Unicef. (2013). Improving child nutrition: the achievable imperative for global progress. New York: UNICEF, 1-14.

Welasih, \& Wirjatmadi. (2012). Peranan Gizi dalam Siklus Kehidupan. Jakarta: Kencana.

WHO. (2014). Infant mortality. World Health Organitation.

Wiyogowati. (2012). Kejadian Stunting Pada Anak Berumur Dibawah Lima Tahun (0-59 Bulan) di Provinsi Papua Barat. Jurnal Kesehatan Masyarakat UI, 16-18. 